\title{
Spatio-Temporal Air Pollutant Characterization for Urban Areas
}

\author{
Nurainshafika Sahak ${ }^{1}$, Arnis Asmat ${ }^{1,2 *}$, Noor Zaitun Yahaya ${ }^{3}$ \\ ${ }^{1}$ School of Chemistry and Environment, Faculty of Applied Sciences, Universiti Teknologi MARA, Selangor, Malaysia \\ ${ }^{2}$ Climate Change \& Carbon Footprint Research Group, Universiti Teknologi MARA, Selangor, Malaysia \\ ${ }^{3}$ Faculty of Ocean Engineering Technology and Informatics, Universiti Malaysia Terengganu, Terengganu, Malaysia \\ Email: nurainshafikasahak06@gmail.com, ^rnis_annis@uitm.edu.my
}

How to cite this paper: Sahak, N., Asmat, A., \& Yahaya, N. Z. (2022). Spatio-Temporal Air Pollutant Characterization for Urban Areas. Journal of Geoscience and Environment Protection, 10, 218-237.

https://doi.org/10.4236/gep.2022.101015

Received: December 21, 2021

Accepted: January 26, 2022

Published: January 29, 2022

Copyright (c) 2022 by author(s) and Scientific Research Publishing Inc. This work is licensed under the Creative Commons Attribution International License (CC BY 4.0).

http://creativecommons.org/licenses/by/4.0/ (c) (i) Open Access

\begin{abstract}
Urban pollution has now become increasingly recognized as an important determinant of air pollution in developed countries. The effect of urban air pollution in developing countries, on the other hand, has not been adequately addressed in the data Spatio-temporal time series. Thus, this study was intended to characterize the effect of urbanization on air pollution for an urbanized Klang Valley, Malaysia using Spatio-temporal data from 2008 to 2017. The Air Pollution Index (API) data and local pollutant concentration were employed to establish the links between urban air pollution. The analysis will be supported by determining the source of pollutants during the study period using Principal Component Analysis (PCA). The study identified that Carbon monoxide (CO), Nitrogen Dioxide $\left(\mathrm{NO}_{2}\right)$, and Ozone $\left(\mathrm{O}_{3}\right)$ are the major air pollution that has contributed to degrading air quality in the Klang Valley due to the vehicles, combustion process, and industries.
\end{abstract}

\section{Keywords}

Urban Pollution, Air Pollution Index (API), Spatio-Temporal

Characterization, Source of Pollutants, Inverse Distance Weighted (IDW),

Principal Component Analysis (PCA)

\section{Introduction}

Understanding the patterns and the magnitude of pollution in the urban environment is increasingly important (Adedeji, Oluwafunmilayo, \& Oluwaseun, 2016). Air pollution occurs when air is contaminated with natural and anthropogenic pollutants associated with human activities, including polluting residuals from consumption and production activity (Mackenzie \& Turrentine, 2021). More fossil 
fuels are burned as urbanization, industrial development, vehicle use, and other environmentally hazardous processes increase, resulting in increased carbon dioxide $\left(\mathrm{CO}_{2}\right)$, nitrogen dioxide $\left(\mathrm{NO}_{2}\right)$, sulfur dioxide $\left(\mathrm{SO}_{2}\right)$, ozone $\left(\mathrm{O}_{3}\right)$, and particulate matter (PM) concentrations in the troposphere (Liu et al., 2012; Tian et al., 2014; Yan et al., 2016). This link exists due to how urbanisation increases the intensity of human social and economic activities, leading to air pollution through fossil fuels (Wang et al., 2020).

Malaysia's air quality decreases gradually because of rapid urbanisation, industrial and population growth (Sentian, Herman, \& Wui, 2019). A study conducted by Azid et al. (2014) shows that air pollution exists only in highly urban areas such as Kuala Lumpur, Johor Bahru, and George Town, Penang. It also found that primary sources of pollutants in Malaysia, natural sources, mobile and anthropogenic sources (Mohd Zizi et al., 2018). Rapid urbanisation also influences traffic emissions that impact the population, economic growth, and activity services, particularly in the city centres. According to the $10^{\text {th }}$ Malaysia Plan, the rate of urbanisation in Malaysia has increased from 25\% in 1960 to $65 \%$ in 2005 , with the expected increase of $75 \%$ of the population residing in the Klang Valley conurbation by 2020 (Shafiee \& Mahmud, 2020).

In Malaysia, private cars, motorcycles, light and heavy vehicles are significant contributors to the deterioration in air quality which is most rapid in urban areas. The total number of newly registered motor vehicles from 2004 to 2017 was 286,771,902 units, comprising five classes: passenger cars, motorcycles, vans/lorries, and taxis/buses (Department of Environment (DOE), 2017). Motorcycles and passenger cars are the dominant classes of motor vehicles, with 6,572,366 units in 2004 that increased by 35\% to 11,989,591 units in 2015 (Department of Environment (DOE), 2015). The same situation was shown for passenger cars, with 5,911,752 units in 2004 that grew by $35 \%$ to $13,173,030$ units in 2017 (Department of Environment (DOE), 2017). Table 1 shows the amount of transportation in Klang for eight years (2010-2017).

These increasing emissions from the transportation sector contribute to domestic air pollution, global climate change, human health problems, and ground-level

Table 1. Amount of transportation for whole Klang Valley in 2010 to 2017 (Sources: Ministry of Transportation (MOT), 2021).

\begin{tabular}{cccccccc}
\hline & Motorcycle & Car & Bus & Taxi & Self-Drive & Logistic & Others \\
\hline 2010 & $1,578,757$ & $3,225,420$ & 17,171 & 23,580 & 725 & 239,108 & 117,535 \\
2011 & $1,678,779$ & $3,476,028$ & 18,056 & 25,760 & 789 & 250,752 & 123,005 \\
2012 & $1,797,664$ & $3,738,904$ & 18,409 & 27,849 & 877 & 263,987 & 129,805 \\
2013 & $1,916,369$ & $4,017,422$ & 18,844 & 29,297 & 1455 & 278,662 & 137,883 \\
2014 & $2,012,759$ & $4,243,408$ & 19,355 & 31,537 & 1843 & 292,884 & 145,087 \\
2015 & $2,155,802$ & $4,223,807$ & 21,317 & 55,978 & 46,334 & 321,935 & 260,364 \\
2016 & $2,165,950$ & $4,502,876$ & 20,522 & 36,513 & 13,201 & 317,080 & 142,138 \\
2017 & $2,229,288$ & $4,576,399$ & 20,904 & 36,672 & 15,880 & 327,914 & 144,890 \\
\hline
\end{tabular}


ozone formation at both regional and national scales (Saija \& Romano, 2002; Azam et al., 2016, Shafiee \& Mahmud, 2020). Generally, the primary sources of urban air pollution to individual health are particulate matter (PM) and nitrogen dioxide $\left(\mathrm{NO}_{2}\right)$ through emission from vehicle exhaust (Ghaffarpasand et al., 2020, Shafiee \& Mahmud, 2020). Similarly, (Zhou et al., 2018) discovered that urbanisation worsens regional $\mathrm{PM}_{2.5}$ pollution.

Therefore, the study provides insight into understanding the healthy level trend in urban areas using the Spatio-temporal characterization of the Air Pollution Index (API). In addition, to determine the significant pollutant to relate as a local emission to the urban air quality degradation.

\section{Materials and Methods}

Klang Valley, centered in Kuala Lumpur, was selected and known as Malaysia's industrial and commercial heartland, and it is densely populated (Awang et al., 2000). The current population in Klang Valley is 7.2 million, which is about a quarter of Malaysia's total population and the region size is $2843 \mathrm{~km}^{2}$. Klang Valley is located in Peninsular Malaysia, and the two types of monsoon that occur in this study area are Northeast and Southwest monsoon. Titiwangsa Mountain geographically delineates this place to the northwest, Semenyih in the southeast, and Port Klang in the Southwest. The region's development occurred primarily in the East-West direction, between Gombak and Port Klang. Nonetheless, the urban areas surrounding Kuala Lumpur have expanded south to the border of Negeri Sembilan and north to Rawang (Azmi et al., 2010).

Table 2 shows that the Air Quality Monitoring Station (AQMS) Klang Valley was located based on different surrounding activities or land use (Sentian, Herman, \& Wui, 2019). The monitoring station is strategically located in four other areas; residential, industrial, busy traffic, and rural area (Afroz, Hassan, \& Ibrahim, 2003). The selection of a location-based on historical and current monitoring, representativeness, accessibility, and availability of support services, security,

Table 2. Air monitoring station in Klang Valley.

\begin{tabular}{cccc}
\hline No Id & \multicolumn{1}{c}{ Station } & Coordinates & Area Category \\
\hline \multirow{2}{*}{ S1 } & Sek. Keb. Batu Muda, Kuala Lumpur & N 3.21260 & Urban \\
& & E 101.68360 & \\
S2 & Sek. Men. Keb. Seri Permaisuri, Cheras & N 3.10700 & Urban \\
& & E 101.71770 & \\
S3 & Sekolah Menengah (P) Raja Zarina, Klang & N 3.01160 & Urban \\
& & E 101.40900 & \\
S4 & Sek. Keb. Bandar Utama, Petaling Jaya & N 3.13150 & Industrial \\
& & E 101.60820 & \\
S5 & Sek. Keb. TTDI Jaya, Shah Alam & N 3.10660 & Urban \\
& & E 101.55730 & \\
S6 & Sek. Keb. Putrajaya 8(2), Jln P8/E2, Putrajaya & N 2.9310 & Urban \\
& & E 101.6804 & \\
\hline
\end{tabular}


and topographic effects. Five from six-station are ranked as urban areas; Batu Muda, Cheras, Klang, Shah Alam, and Putrajaya, while the station in Petaling Jaya was ranked as Industrial area. The stations of Klang and Shah Alam are located in the Klang Valley's central region. Klang station is in an immediate industrialized area with congested main roads and is close to Port Klang, a busy port. Station contrast, Shah Alam station is surrounded by busy highways and is located in residential and commercial areas. According to (Fang et al., 2015), Cheras and Petaling Jaya stations are located on the main roads of industrial and high-density residential areas, frequently affected by traffic-related pollution., for visualizing contrast, Putrajaya station is located in a less polluted area surrounded by residential areas and major roads. Station in Batu Muda is located in central Kuala Lumpur, a highly congested area with a total population of 1.76 million (2016) (Rahman et al., 2015). Malaysia Ambient Air Quality standard air pollution index (API) and the concentration of pollutants depends on varying time averages. The Air Pollution Index (API) is calculated using the sub-indices of air pollutants; Ozone $\left(\mathrm{O}_{3}\right)$, Carbon monoxide $(\mathrm{CO})$, Sulfur Dioxide $\left(\mathrm{SO}_{2}\right)$, Particulate Matter $\left(\mathrm{PM}_{10}\right)$, and Nitrogen Dioxide $\left(\mathrm{NO}_{2}\right)$, and only the highest sub-indices of each pollutant were used as API values (Afroz et al., 2003). Air Pollution Index (API)'s daily data for ten years from 2008 to 2017 were obtained from the Department of Environment (DOE) via a private company as Alam Sekitar Malaysia Sdn Bhd (ASMA) for all stations in Klang Valley.

\section{Methods}

For temporal characterization Air Pollution Index (API) trend follows with time series of annual average analysis of air pollutants; Ozone $\left(\mathrm{O}_{3}\right)$, Carbon Monoxide (CO), Sulfur Dioxide $\left(\mathrm{SO}_{2}\right)$, Particulate Matter $\left(\mathrm{PM}_{10}\right)$, and Nitrogen Dioxide $\left(\mathrm{NO}_{2}\right)$ were plotted.

The ten years of annual average Air Pollution Index (API) was interpolated to observe the spatial distribution. The interpolation technique with geographical information system (GIS) software was applied to interpolate the air quality data to determine the distribution of the pollutants. geographical information system (GIS) integration in this study helps visualize air pollution dispersion and evaluate the association between the high concentration level and potential pollution sources. The general concept of Inverse Distance Weigthed (IDW) is to estimate the unknown value of $Y\left(X_{0}\right)$ in location $X_{0}$ given the observed $Y$ value at sampled locations $X_{i}$ according to the formula in Equation (1) (Hussein \& Abdullah, 2019).

$$
Y\left(X_{0}\right)=\sum_{i=1}^{n} \lambda_{i} Y\left(X_{i}\right)
$$

According to (Gimond 2021), principal component analysis (PCA) is a dimensional reduction method that is often used to reduce the dimensionality of large data sets by transforming large data sets into smaller ones without changing the information. The small data sets are easier to explore and visualize and make the data analyzing process easier and faster for machine learning algorithms without an extraneous variable to process. In this study, principal com- 
ponent analysis (PCA) has been performed to determine the significant pollutant in study areas. Identification and observation of variation's source taking place after reduction of data set and generally written in the following mathematical Equation (2):

$$
P C_{i}=l_{1 i} X_{1}+l_{2 i} X_{2}+\cdots+l_{n i} X_{n}
$$

where $P C_{i}$ is define as $t$ th principal component, $l_{j i}$ is define as variable loading and $X_{j}$ is define as observed variable (Jamalani et al., 2016).

\section{Results and Discussions}

\subsection{Temporal of API and Pollutants}

As shown in the graph, Figures 1-6 panel (a) is the time series trend of daily API

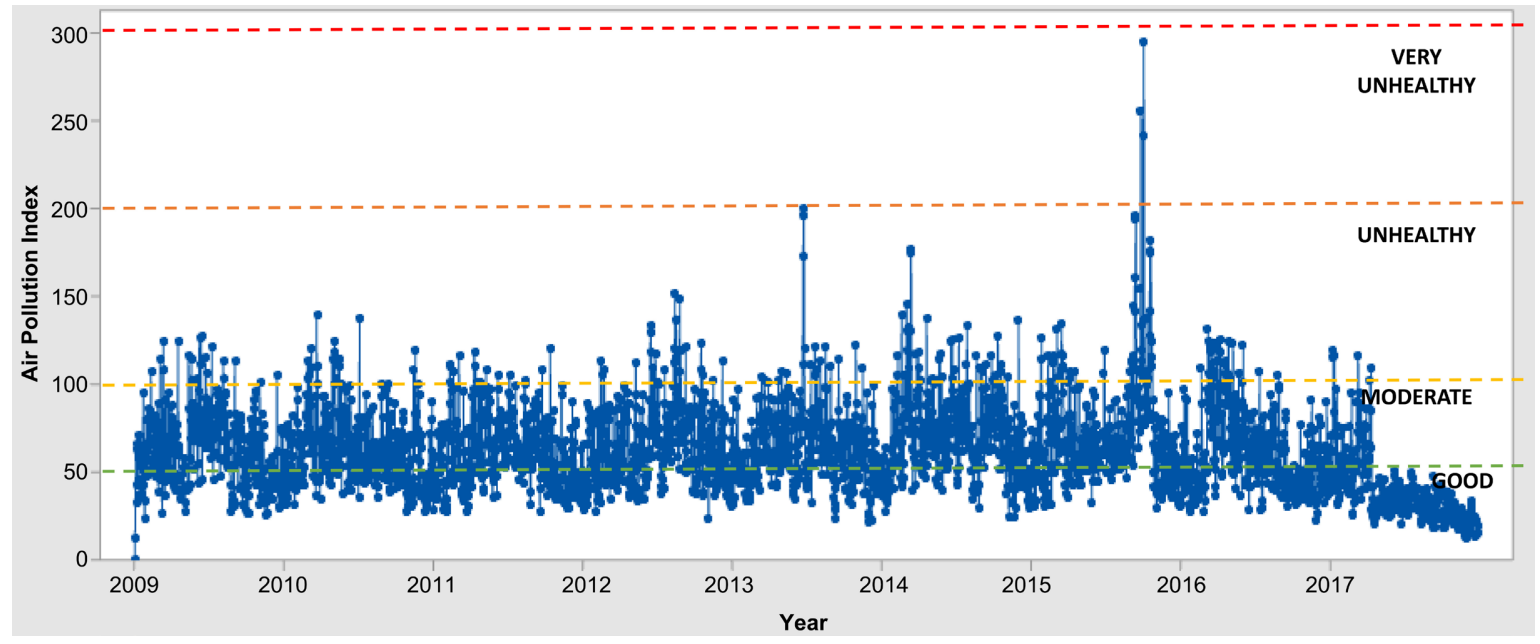

(a)

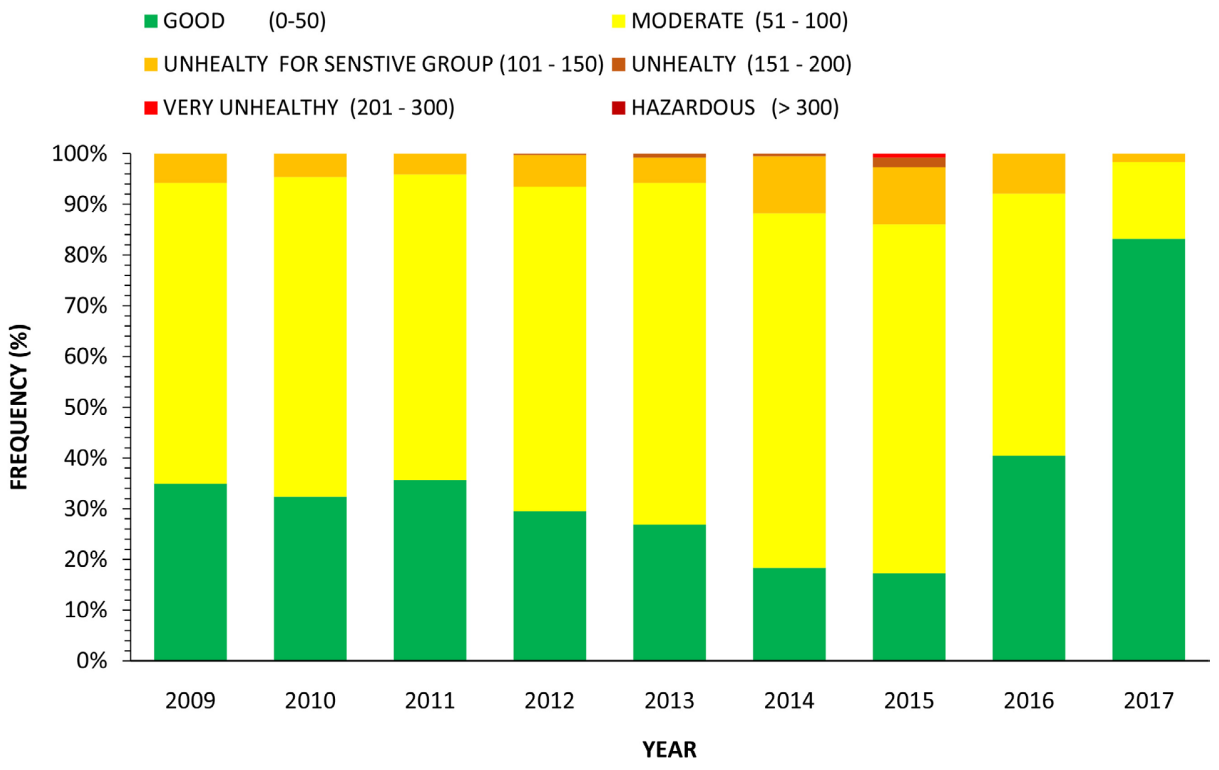

(b)

Figure 1. (a) Trend of air pollution index (API) for Batu Muda from 2008 to 2017 (b) Annual frequency of air pollution index (API) categories followed Malaysian ambient air quality standard (MAAQS). 


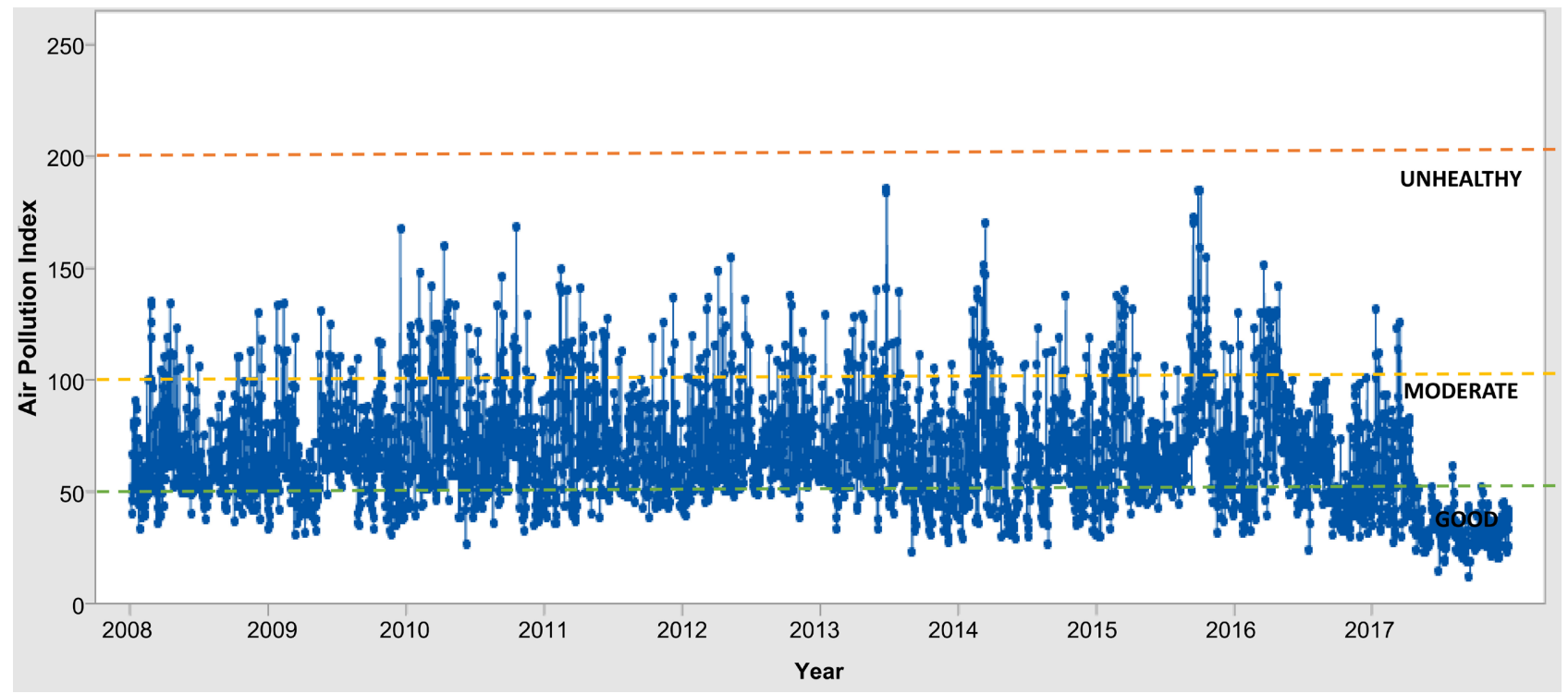

(a)

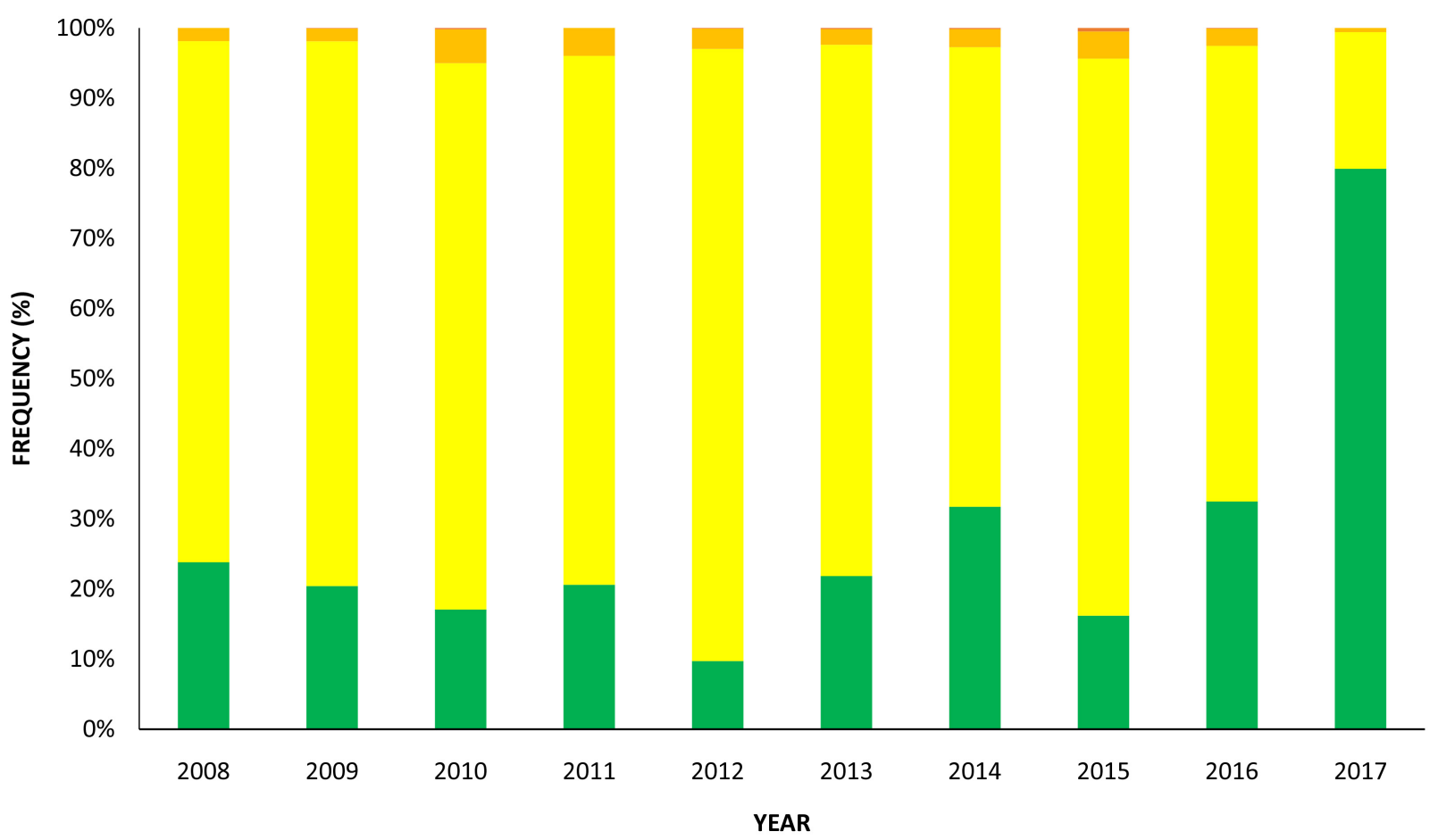

(b)

Figure 2. (a) Trend of air pollution index (API) for Cheras from 2008 to 2017 (b) Annual frequency of air pollution index (API) categories followed Malaysian ambient air quality standard (MAAQS).

value years for each station while panel (b) the annual frequencies of Air Pollution Index (API) categories for ten years of data. The daily reading of API was compared to the Malaysian Ambient Air Quality Standard (MAAQS). From all agglomeration where the monitoring station is located, the Air Pollution Index (API) trend shows that most of the stations in Klang Valley from 2008 to 2017 are at unhealthy levels. Moreover, Klang and Shah Alam are found at hazardous 


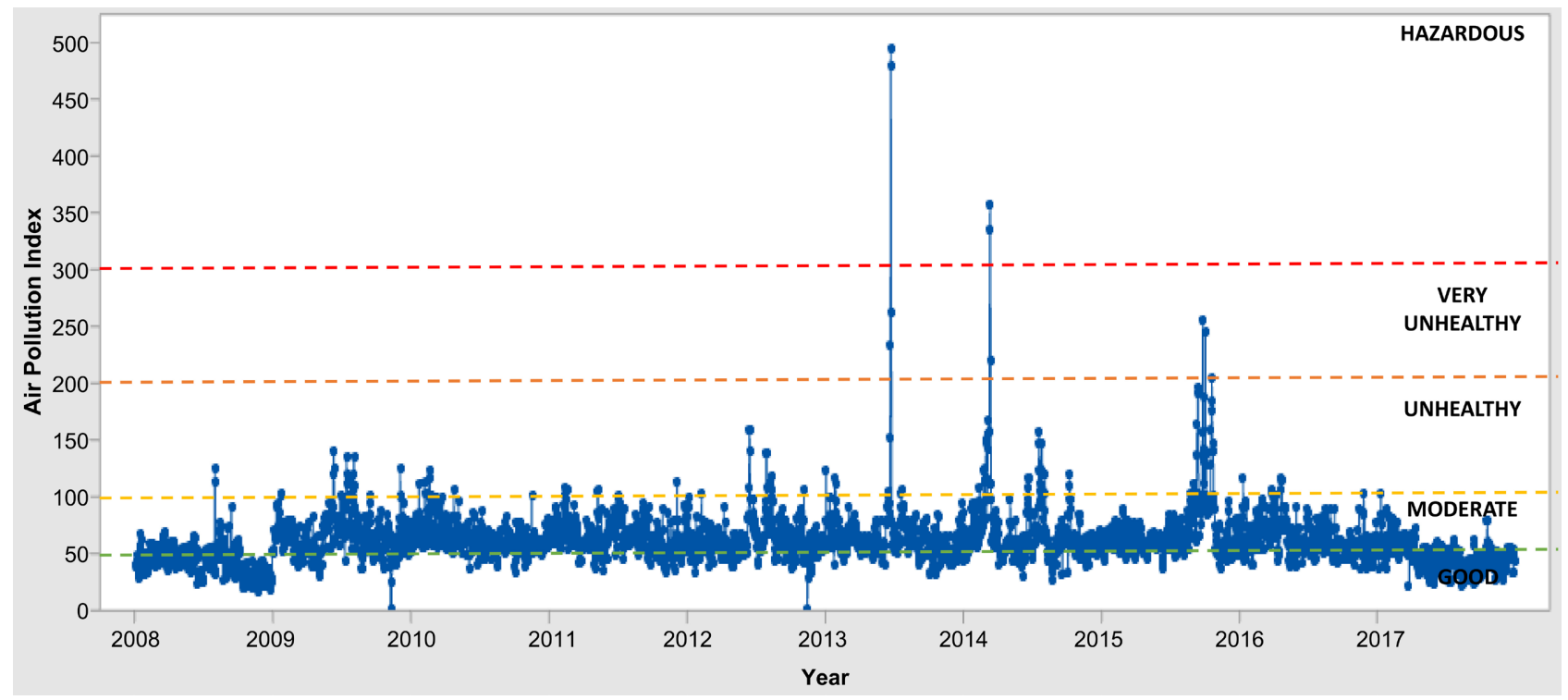

(a)

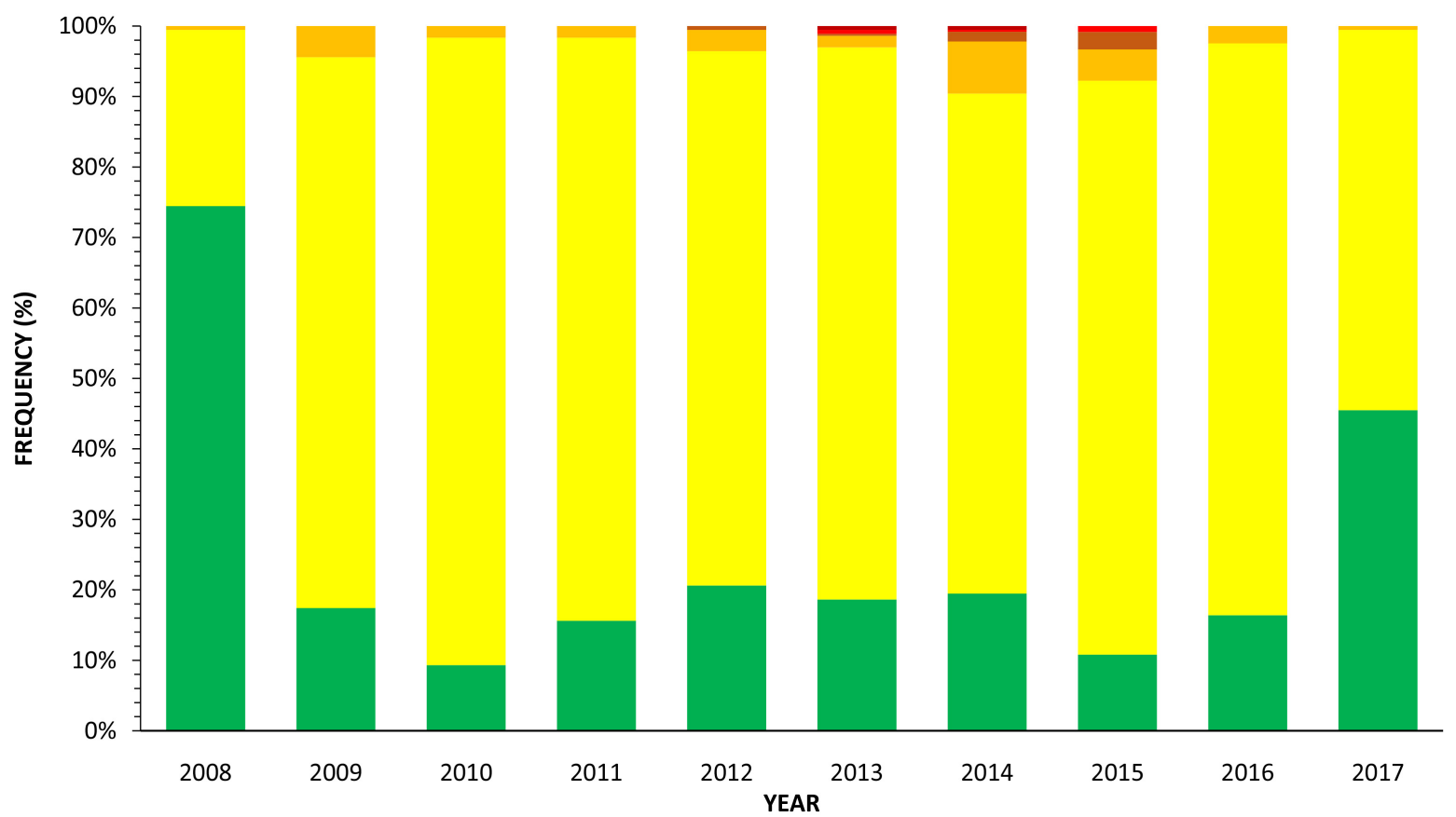

(b)

Figure 3. (a) Trend of air pollution index (API) for Klang from 2008 to 2017 (b) Annual frequency of air pollution index (API) categories followed Malaysian ambient air quality standard (MAAQS).

levels with API values greater than 300. For the Klang station, Air Pollution Index (API) with values of more than 300 were recorded between middle 2013 to early 2014, while for Shah Alam, the Air Pollution Index (API) value was detected in the middle of 2013 and 2015. The highest Air Pollution Index (API) recorded is 495 at Klang, which is hazardous.

Figures 1(b)-5(b) identify the category "moderate" as dominant for the agglomerations were stations located in compact urban activities. This finding 
N. Sahak et al.

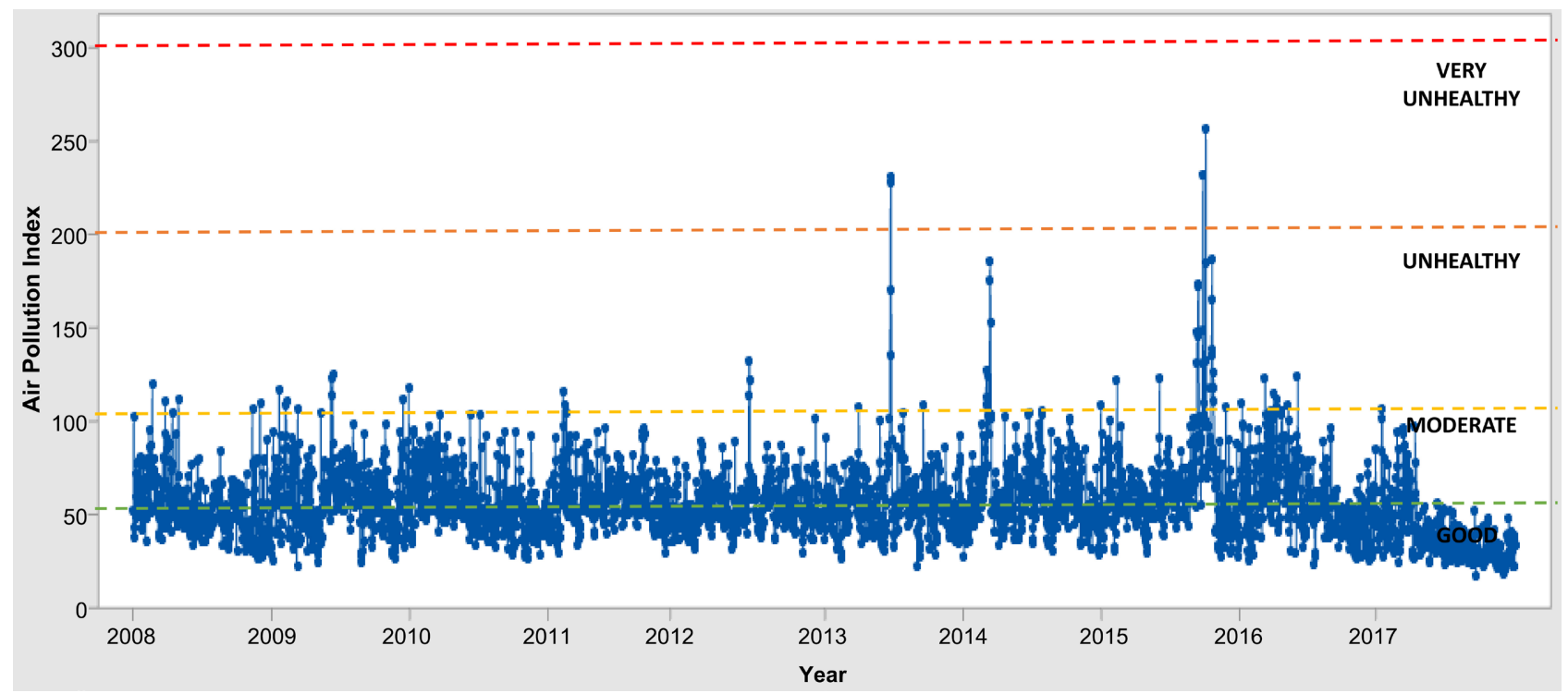

(a)

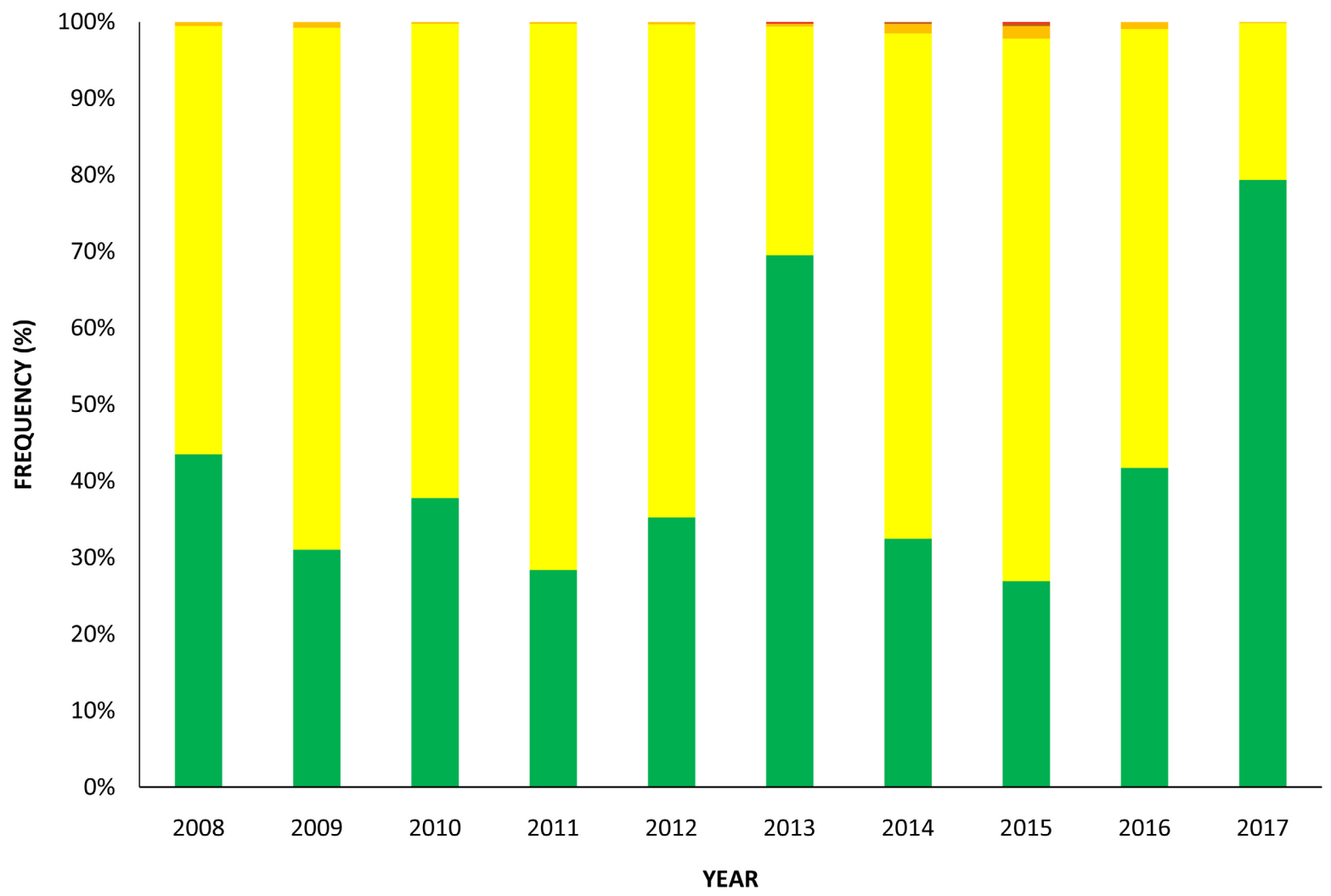

(b)

Figure 4. (a) Trend of air pollution index (API) for Petaling Jaya from 2008 to 2017 (b) annual frequency of air pollution index (API) categories followed Malaysian ambient air quality standard (MAAQS).

shows that all monitoring stations recorded moderate air pollution even without haze episodes. This finding might be due to pollutant emissions from local sources, such as anthropogenic emissions as contributing factors (Jang et al., 2017; Nerriere et al., 2005). 


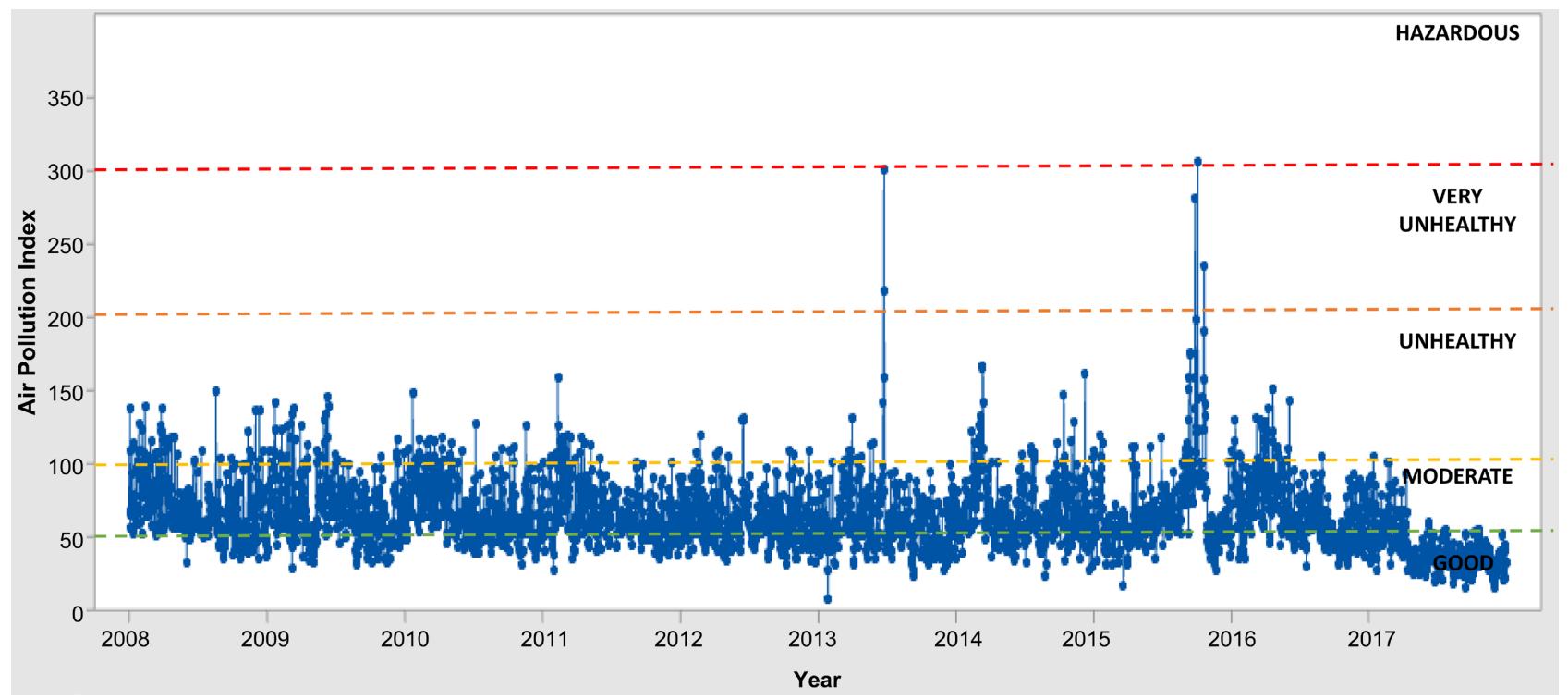

(a)

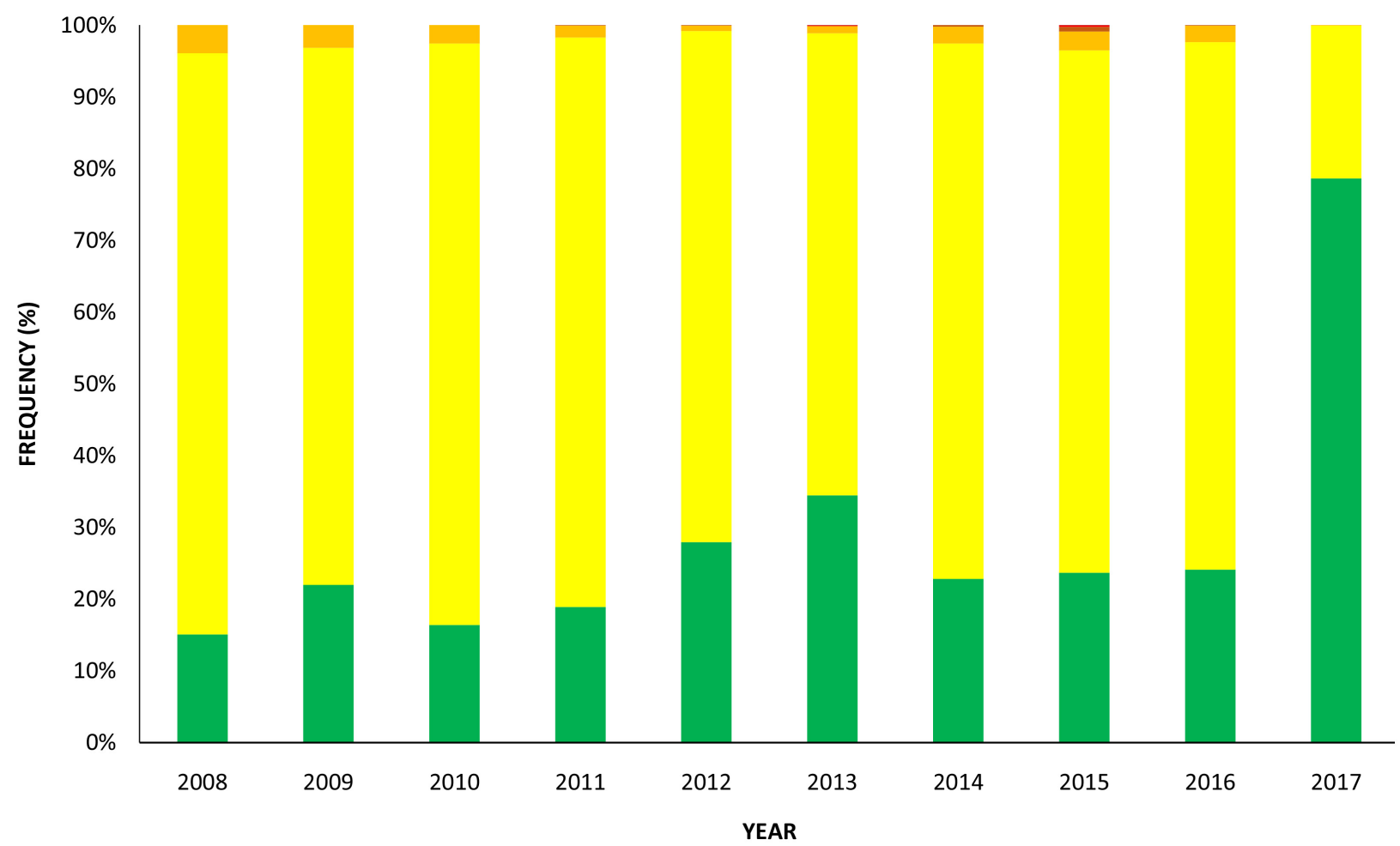

(b)

Figure 5. (a) Trend of air pollution index (API) for Shah Alam from 2008 to 2017 (b) annual frequency of air pollution index (API) categories followed Malaysian ambient air quality standard (MAAQS).

Figure 7 illustrates the annual trends of air pollutants; Ozone $\left(\mathrm{O}_{3}\right)$, Carbon monoxide (CO), Sulfur Dioxide $\left(\mathrm{SO}_{2}\right)$, Particulate Matter $\left(\mathrm{PM}_{10}\right)$, and Nitrogen Dioxide $\left(\mathrm{NO}_{2}\right)$ in Klang Valley from 2008 to 2017. The annual average of concentration is between moderate and reasonable categories of Malaysian Ambient Air Quality Standard (MAAQS). 


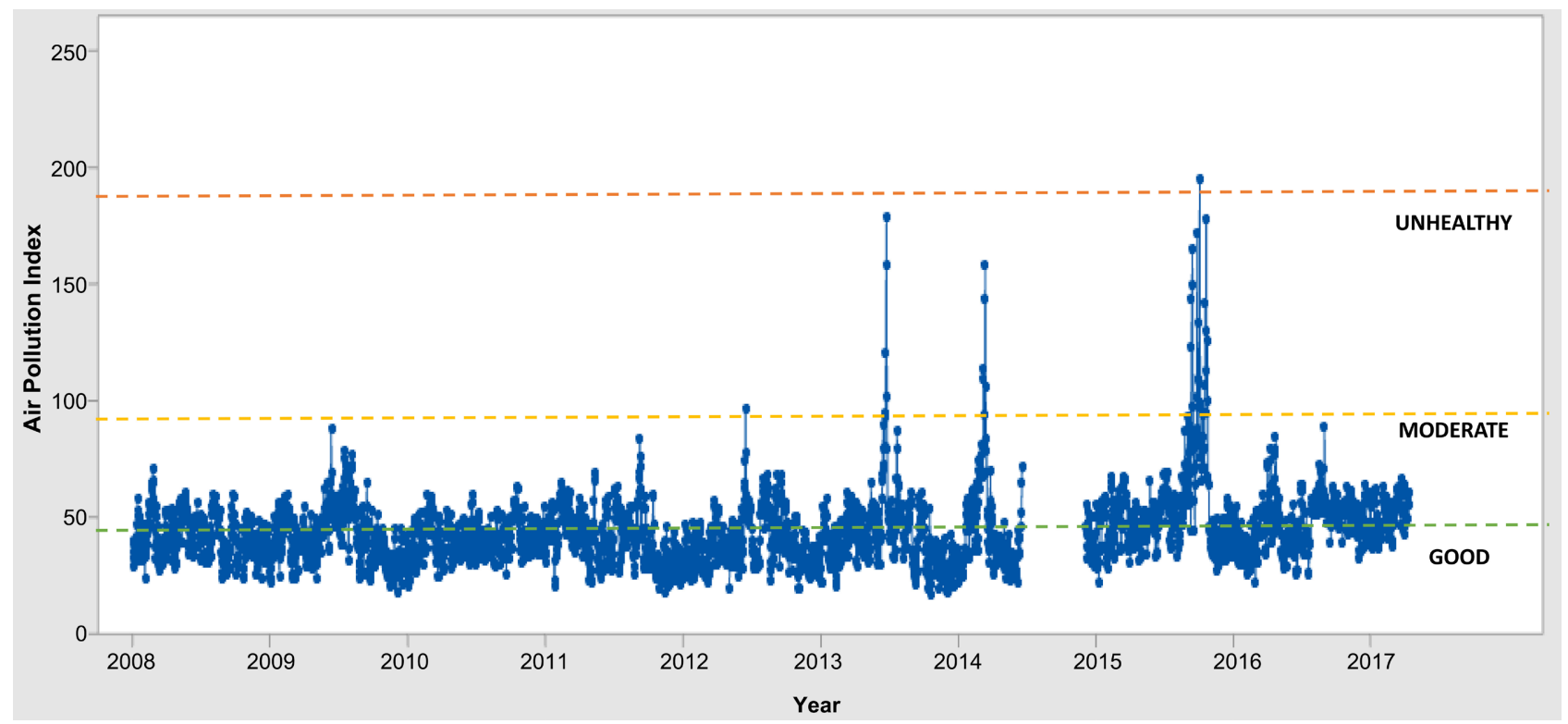

(a)

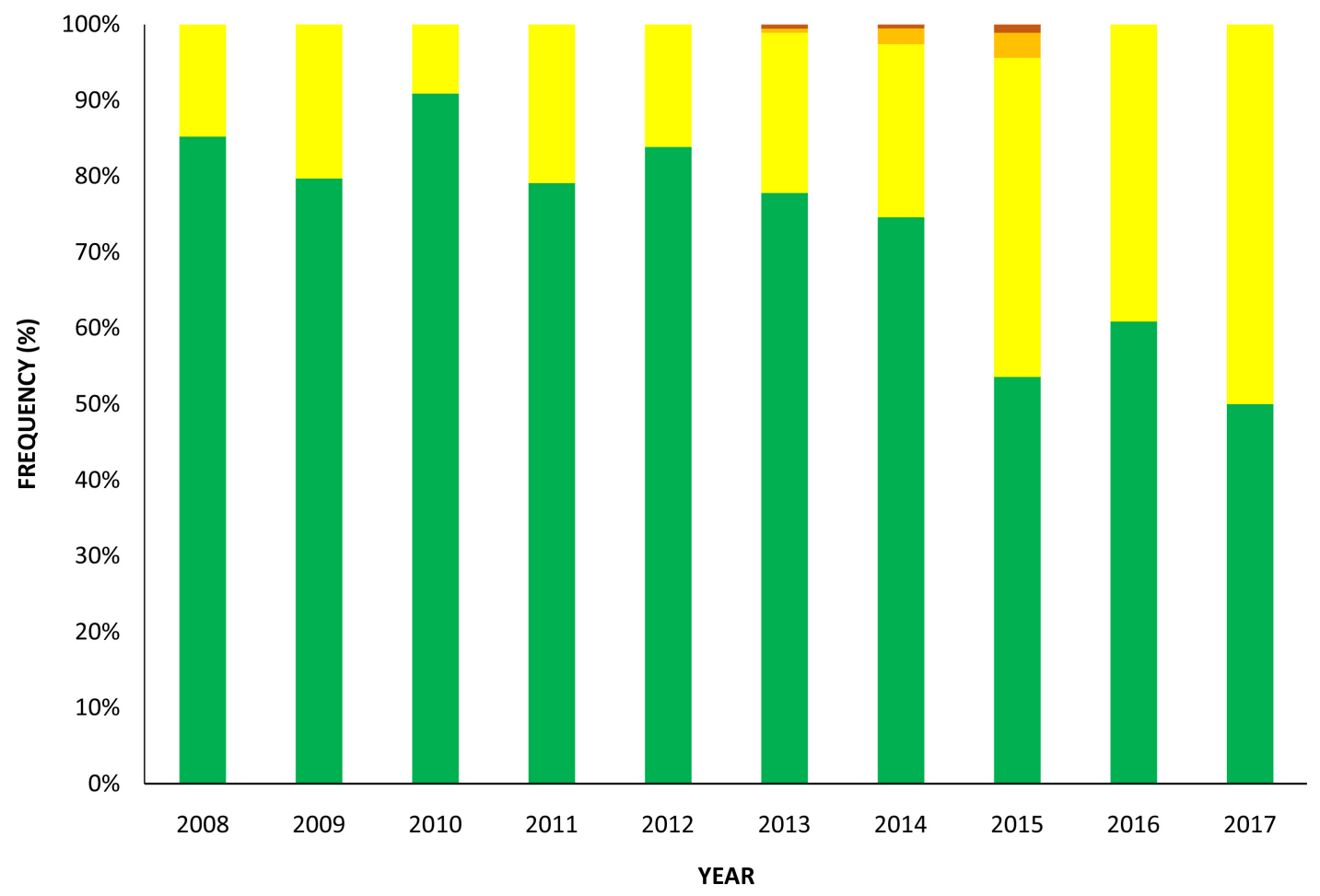

(b)

Figure 6. (a) Trend of air pollution index (API) for Putrajaya from 2008 to 2017 (b) Annual frequency of air pollution index (API) categories followed by Malaysian ambient air quality standard (MAAQS).

The trends show that Klang station recorded high concentrations of all pollutants except Nitrogen Dioxide $\left(\mathrm{NO}_{2}\right)$. Klang station is located in the center of Selangor and the hub of industrial activities and transportation. One of the busier ports in Malaysia, Port Klang, might contribute to the heavy traffic congestion from the port (Shah et al., 2010; Department of Environment (DOE), 2011). 
Annual Trend of Ozone $\left(\mathrm{O}_{3}\right)$ for 10 years

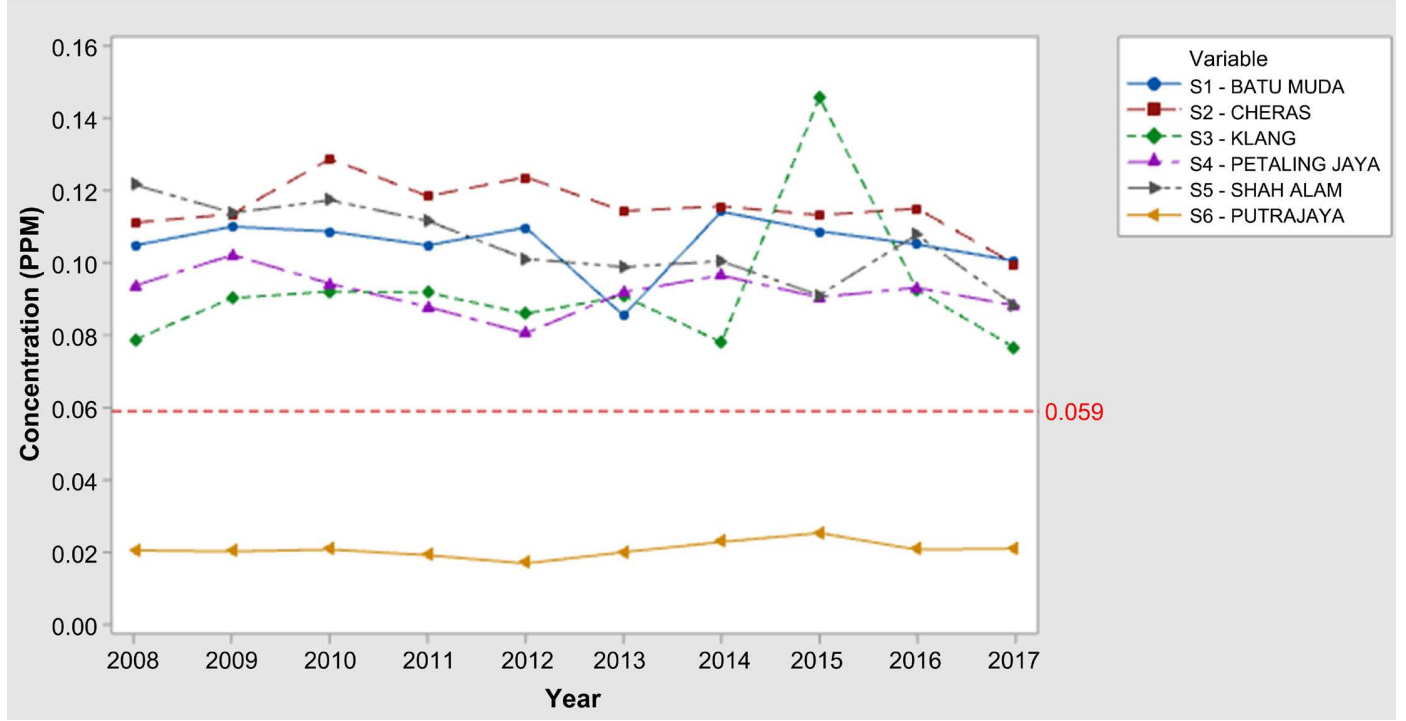

Annual Trend of Carbon Monoxide (CO) for 10 years

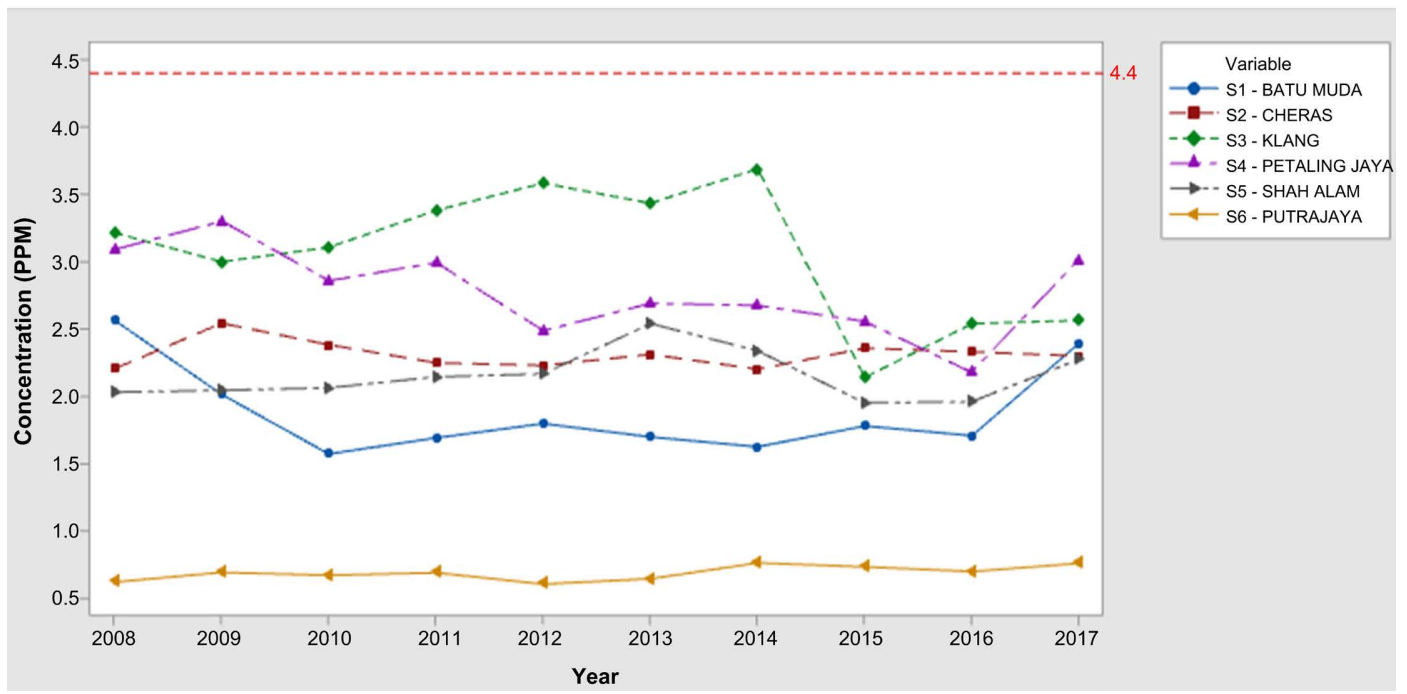

Annual Trend of Sulphur Dioxide $\left(\mathrm{SO}_{2}\right)$ for 10 years

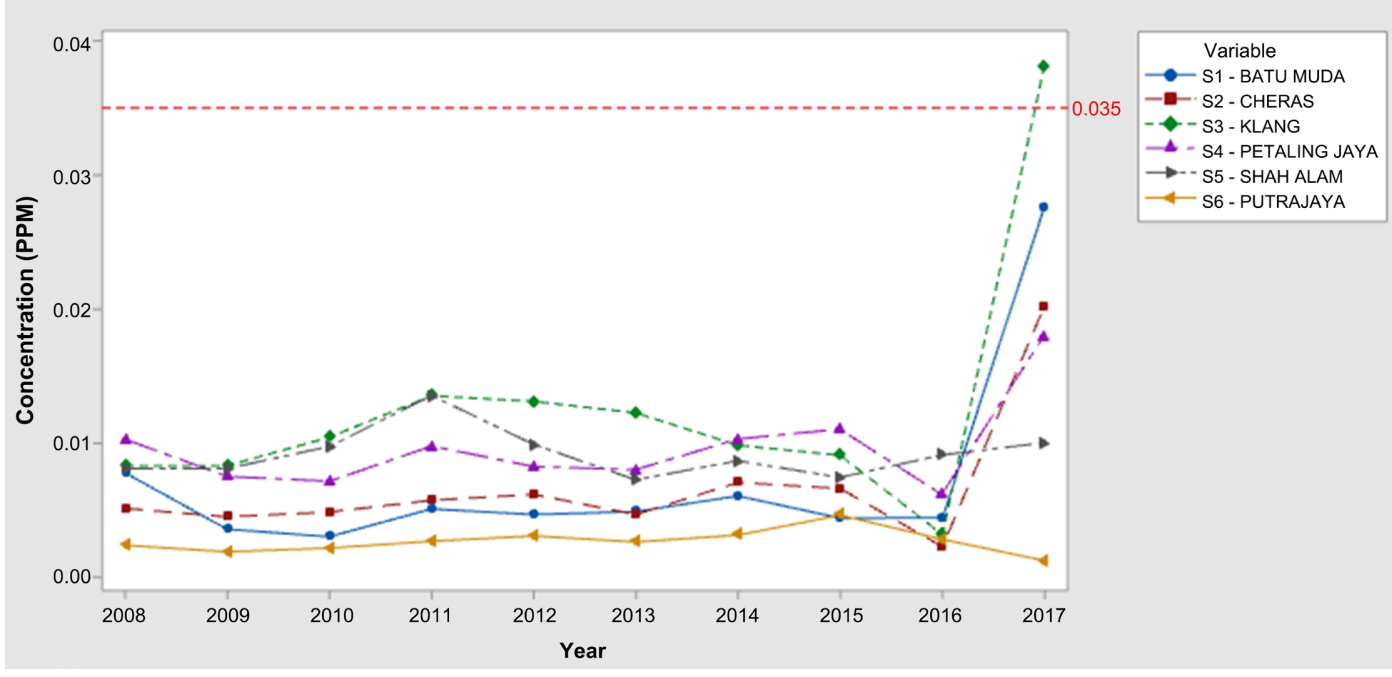




\section{Annual Trend of Particulate Matter $\left(\mathrm{PM}_{10}\right)$ for 10 years}

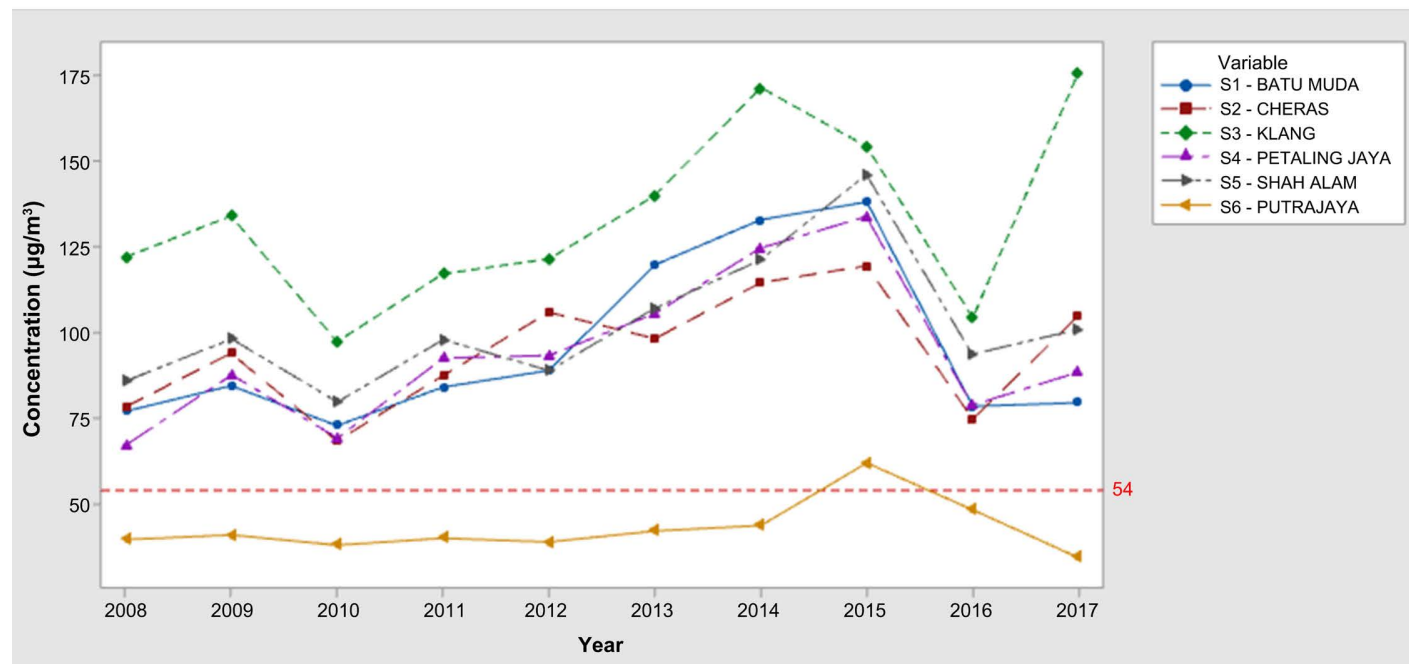

Annual Trend of Nitrogen Dioxide $\left(\mathrm{NO}_{2}\right)$ for 10 years

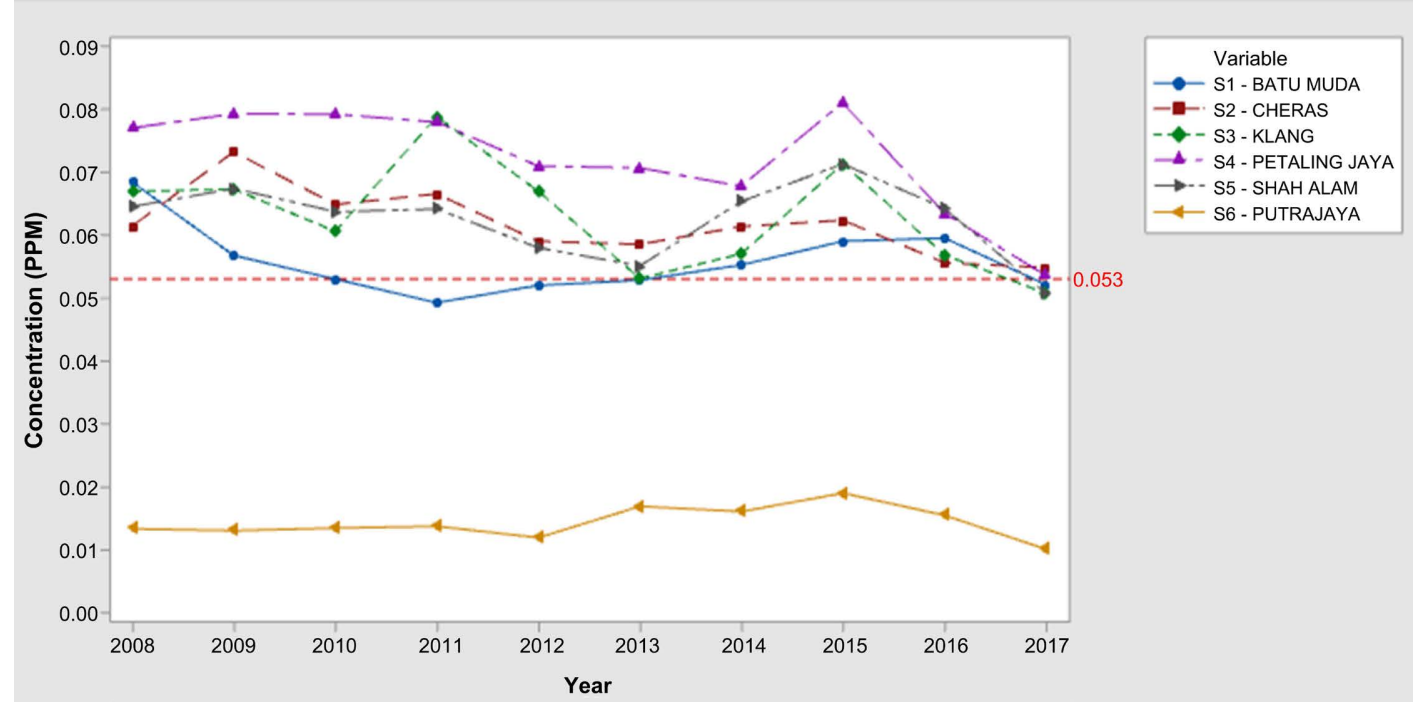

Figure 7. Annual trends of ozone $\left(\mathrm{O}_{3}\right)$, carbon monoxide $(\mathrm{CO})$, sulfur dioxide $\left(\mathrm{SO}_{2}\right)$, nitrogen dioxide $\left(\mathrm{NO}_{2}\right)$ (ppm) and particulate matter $\left(\mathrm{PM}_{10}\right)\left(\mu \mathrm{g} / \mathrm{m}^{3}\right)$ in Klang Valley from 2008 to 2017.

The Petaling Jaya station was surrounded by many industries and residential and commercial areas (Rahman et al., 2015). In a study by Abdullah et al. (2018), Nitrogen Dioxide $\left(\mathrm{NO}_{2}\right)$ pollutants come from transportation. Almost 2.2 million vehicles were registered in Selangor and Petaling Jaya as one city with a high number of vehicles. Open burning activities, long-range transport of air pollutants, and domestic fuel sources are also known as main Nitrogen Dioxide $\left(\mathrm{NO}_{2}\right)$ concentrations (Rajab et al., 2011).

\subsection{Spatial Distribution of API}

Figure 8 depicts an Inverse Distance Weighted (IDW) interpolation map of the Annual Average of Air Quality Index (API) followed Malaysian Air Quality Standard (MAAQS) categories of Air Quality Index (API) in Klang Valley over 

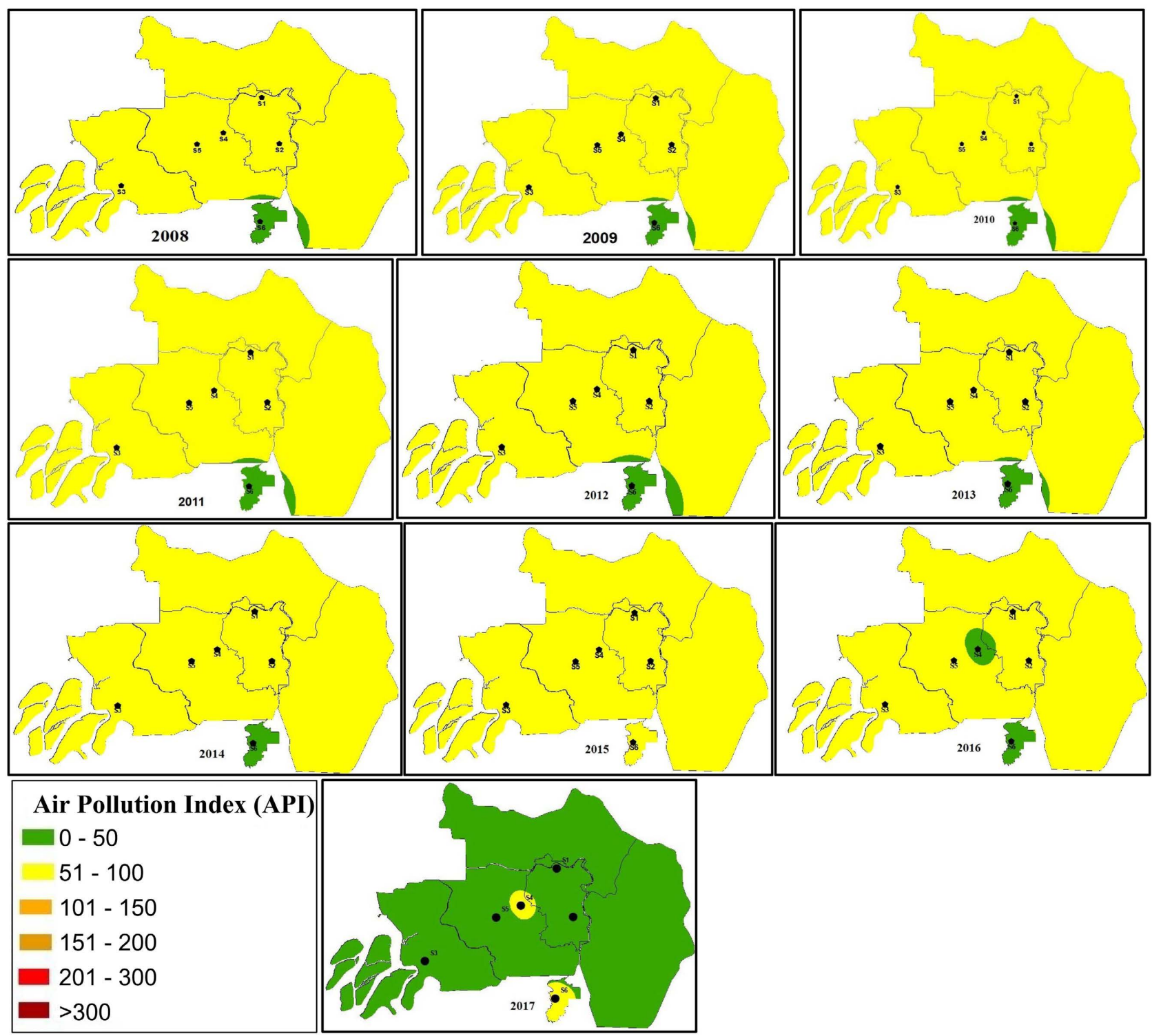

Figure 8. Spatial interpolation of annual average Air Pollution index (API) followed Malaysian ambient air quality standard (MAAQS).

ten years. The six points on each map represent the location of Air Quality Monitoring Station (AQMS) in the study area. The Air Quality Index (API) reading was interpolated, and the reading decreased as the distance from the monitoring station increased. Interpolation results showed that the distribution of Air Quality Index (API) from 2008 to 2014 is the same, while all stations recorded moderate Air Quality Index (API) in 2015. However, in 2016 and 2017, Putrajaya and Petaling Jaya had low and high Air Quality Index (API) distributions, respectively, compared to other stations.

\subsection{Sources of Pollutant Determination Using Principal Component Analysis (PCA)}

The Principal Component Analysis (PCA) was applied to five parameters to 
identify the most significant parameter besides understanding the multiple sources of pollutants contributing to air pollution in the Klang Valley region. The parameter was air pollutants; Ozone $\left(\mathrm{O}_{3}\right)$, Carbon Monoxide (CO), Sulfur Dioxide $\left(\mathrm{SO}_{2}\right)$, Particulate Matter $\left(\mathrm{PM}_{10}\right)$, and Nitrogen Dioxide $\left(\mathrm{NO}_{2}\right)$.

Table 3 shows the eigenvalues for each linear component which only two principal components (PCs) were found for each station. Dominick et al. (2012) stated that only strong factor loading was selected for the principal components (PCs) interpretation. The variability of each station is approximately 62.34 percent (Batu Muda), 59.54 percent (Cheras), 58.99 percent (Klang), 58.88 percent (Petaling Jaya), 56.43 percent (Shah Alam), and 59.93 percent for Putrajaya.

After determining the number of eigenvalues, rotation was applied to the selected principal components (PCs) to enable interpretation. Varimax factors (VFs) were obtained from the process after it was used. The Varimax factors (VFs) with values greater than 0.75 were chosen as criteria in this study because they are solid and stable, and they display moderate to solid loadings on the extracted component (Azid et al., 2015). Four of the five air quality variables utilized in this study meet the 0.75 -factor loading requirement, as shown in Table 4 Carbon Monoxide (CO), Nitrogen Dioxide $\left(\mathrm{NO}_{2}\right)$, Ozone $\left(\mathrm{O}_{3}\right)$ are the pollutants in consideration. The potential contribution of pollution in the Klang Valley monitoring station is then assigned to these pollutants. Furthermore, VF1 of all stations except Putrajaya has a high positive factor loading toward Carbon Monoxide (CO) while for Nitrogen Dioxide $\left(\mathrm{NO}_{2}\right)$, only Cheras, Petaling Jaya, Shah Alam. As for Particulate Matter $\left(\mathrm{PM}_{10}\right)$ only Batu Muda and Putrajaya has high positive of VF1.

This result shows VF1for all sites contribute to traffic-related emissions (Papamanolis et al., 2015). Meanwhile, the second VF shows positive factor loading

Table 3. Eigenvalue of factor from principal component analysis (PCA).

\begin{tabular}{ccccc}
\hline \multirow{2}{*}{ Component } & \multicolumn{3}{c}{ Rotation Sums of Squared Loadings } \\
\cline { 3 - 5 } Batu Muda & 1 & Total & \% of Variance & Cumulative \% \\
\hline \multirow{2}{*}{ Cheras } & 2 & 1.853 & 37.064 & 37.064 \\
& 1 & 1.725 & 34.507 & 62.386 \\
\hline \multirow{2}{*}{ Klang } & 2 & 1.251 & 25.029 & 34.507 \\
& 1 & 1.861 & 37.210 & 59.536 \\
\hline \multirow{2}{*}{ Petaling Jaya } & 2 & 1.089 & 21.783 & 37.210 \\
& 1 & 1.630 & 32.593 & 32.993 \\
\hline \multirow{2}{*}{ Shah Alam } & 2 & 1.315 & 26.291 & 58.884 \\
\hline \multirow{2}{*}{ Putrajaya } & 1 & 1.692 & 33.836 & 33.836 \\
& 2 & 1.130 & 22.598 & 56.434 \\
\hline & 1 & 1.550 & 31.002 & 31.002 \\
& 2 & 1.446 & 28.923 & 59.925
\end{tabular}


Table 4. Factor loading after varimax rotation for six stations.

\begin{tabular}{|c|c|c|c|c|c|c|c|c|c|c|c|c|}
\hline & & & & & & 3 & $S$ & 4 & & 5 & & 6 \\
\hline & & & & & $\mathrm{Va}$ & $\operatorname{imax} \mathrm{F}$ & actor & VF) & & & & \\
\hline & 1 & 2 & 1 & 2 & 1 & 2 & 1 & 2 & 1 & 2 & 1 & 2 \\
\hline $\mathrm{O}_{3}$ & 0.66 & 0.38 & & 0.78 & 0.66 & -0.18 & -0.18 & 0.80 & & 0.75 & 0.61 & -0.44 \\
\hline $\mathrm{CO}$ & 0.80 & 0.12 & 0.83 & & 0.76 & 0.20 & 0.78 & -0.15 & 0.82 & -0.17 & 0.73 & 0.20 \\
\hline $\mathrm{SO}_{2}$ & & 0.81 & & 0.66 & 0.22 & 0.85 & 0.60 & & 0.19 & 0.66 & & 0.74 \\
\hline $\mathrm{PM}_{10}$ & 0.86 & & 0.67 & 0.46 & 0.74 & 0.12 & 0.23 & 0.77 & 0.61 & 0.27 & 0.78 & 0.36 \\
\hline $\mathrm{NO}_{2}$ & 0.21 & 0.67 & 0.76 & & 0.50 & -0.53 & 0.76 & 0.25 & 0.78 & 0.16 & 0.20 & 0.73 \\
\hline
\end{tabular}

is Ozone $\left(\mathrm{O}_{3}\right)$. Interestingly, only three out of six stations shown a solid positive contribution toward Ozone $\left(\mathrm{O}_{3}\right)$. The VF factor loading for Cheras (0.78), Petaling Jaya (0.80), and Shah Alam (0.75), respectively. In addition, Petaling Jaya also exhibit high positive factor loading with Particulate Matter $\left(\mathrm{PM}_{10}\right)$ with a value of 0.77. Two stations; Batu Muda and Klang have high positive toward Sulfur Dioxide $\left(\mathrm{SO}_{2}\right)$ with values 0.81 and 0.85 .

As can be observed from the above, Carbon Monoxide (CO) was one of the major pollutants in Klang Valley, together with Nitrogen Dioxide $\left(\mathrm{NO}_{2}\right)$ and Ozone $\left(\mathrm{O}_{3}\right)$. Carbon Monoxide (CO) has been identified as one of the primary environmental air pollution sources in Klang Valley especially Shah Alam, according to prior studies. Carbon Monoxide (CO) is mostly produced by incomplete combustion of fuel in motor vehicles (Dominick et al., 2012) which transportation sector is responsible for $77 \%$ of Carbon Monoxide (CO) emissions worldwide (Rahman et al., 2015). Studies by Makmom et al. (2012) have predicted that motor vehicles in Malaysia are one of the major contributors to the deterioration of atmospheric conditions.

The following significant contaminant is Nitrogen Dioxide $\left(\mathrm{NO}_{2}\right)$. A study by Isiyaka et al., (2015) Nitrogen Dioxide $\left(\mathrm{NO}_{2}\right)$ emissions are primarily caused by industrial activities as well as traffic congestion. As a result, motor vehicle emissions in high-traffic areas were the primary source of Nitrogen Dioxide $\left(\mathrm{NO}_{2}\right)$. This assertion was also supported by a study conducted by (Dominick et al., 2012) which concluded that Nitrogen Dioxide $\left(\mathrm{NO}_{2}\right)$ is a byproduct of heavy traffic and industrial activity.

The study also revealed that Ozone $\left(\mathrm{O}_{3}\right)$ is amongst the prevalent pollutant in urban areas. It is considered as the primary component of smog formed by photochemical oxidation of its precursor Nitrogen monoxide $\left(\mathrm{NO}_{\mathrm{x}}\right)$, Carbon monoxide (CO) and Volatile Organic Compounds (VOCs) (Banan et al., 2013, Isiyaka et al., 2015). A study from Sadanaga et al. (2012) stated that concentration of Ozone $\left(\mathrm{O}_{3}\right)$, especially in urban and suburban is probably contributed by Nitrogen monoxide $\left(\mathrm{NO}_{\mathrm{x}}\right)$ and the downwind plume of Ozone $\left(\mathrm{O}_{3}\right)$ precursors from industrial activities (Wei et al., 2012, Monteiro et al., 2012).

According to Zakaria et al. (2017), Particulate Matter $\left(\mathrm{PM}_{10}\right)$ was produced by 
point sources such as power generating, industrial operations, construction sites, and automobile emissions. In Shah Alam, non-point sources included soil dust, open burning activity around the research area, and Sumatra bush burning (Isiyaka et al., 2015, Vallero, 2014). Particulate Matter $\left(\mathrm{PM}_{10}\right)$ is also formed as a secondary pollutant by photo chemical oxidation of its precursors in favorable air conditions (Rahman et al., 2015, Isiyaka et al., 2015). It was the primary component of dust fall that moved from a source to an on-source location.

In addition, Sulfur Dioxide $\left(\mathrm{SO}_{2}\right)$ was also detected as one of the potential major pollutants in this study. According to Sahrir et al., 2014, Sulfur Dioxide $\left(\mathrm{SO}_{2}\right)$ is an acidic gas in the air that converts to sulfuric acid under moist conditions or to sulfate under dry conditions. Major Sulfur Dioxide $\left(\mathrm{SO}_{2}\right)$ problems now tend to occur only in cities where coal is still widely used for domestic heating, industry, and power plants (Sahrir et al., 2019). Because many power plants are now located away from urban areas, Sulfur Dioxide $\left(\mathrm{SO}_{2}\right)$ emissions may have an impact on air quality in both rural and urban areas. Even low concentrations can cause a decrease in lung function in asthmatics (World Health Organization, 2018). Sulfur Dioxide $\left(\mathrm{SO}_{2}\right)$ is more harmful when particulate and other pollution levels are high.

\section{Conclusion}

In conclusion, the Spatio-temporal characterization technique successfully identified the selected air quality parameters as well as the pattern of air monitoring stations in Klang Valley, Malaysia. Temporally of ten years (2008-2017), approximately $56 \%$ frequency of days on air quality in Klang Valley was recorded as a moderate category. Meanwhile, five percent was classified as unhealthy to hazardous. Cheras station was identified as the most polluted station which recorded 696 unhealthy days followed by Shah Alam and Batu Muda with 544 and 454 were recorded unhealthy to hazardous respectively. Meanwhile, the rest of the stations were recorded below 300 unhealthy days. A similar pattern of Air Quality Index (API) is distributed at all stations at good to moderate. Putrajaya is the only station that has shown spatially good air quality. Overall the air pollutant's trend shows that major pollutant concentrations are within Malaysia's Ambient Air Quality Standard (MAAQS). Some stations are subjected to the highest levels of pollutants with daily observation. Four pollutants in annual observation, Klang station exhibited high concentrations of Ozone $\left(\mathrm{O}_{3}\right)$, Carbon Monoxide (CO), Sulfur Dioxide $\left(\mathrm{SO}_{2}\right)$, and Particulate Matter $\left(\mathrm{PM}_{10}\right)$. It also found that Petaling Jaya consistently recorded a high concentration of Nitrogen Dioxide $\left(\mathrm{NO}_{2}\right)$. Three major pollutants are Carbon Monoxide (CO), Nitrogen Dioxide $\left(\mathrm{NO}_{2}\right)$ and Ozone $\left(\mathrm{O}_{3}\right)$, found high at almost stations at Klang Valley, which indicated traffic-related emissions. Furthermore, Particulate Matter $\left(\mathrm{PM}_{10}\right)$ is also identified as a significant pollutant in different types of urban activities, for instance, Putrajaya Station is known as an administrative urban type. The rapid growth of urbanization and industrialization where the progressive 
expansion suburbs into closer proximity to an industrial plant in certain areas has led to the problem of air pollution becoming an increasingly important issue. Industrial activities as one contributor of the Air Quality Index (API) level also need attention. Enforcing regulations by the government regarding industrial activities can help Air Quality Index (API) value at the healthy level. Therefore, comprehensive studies involving emission inventory, industrial emission are needed. Statistical models for detecting where and when pollutants could occur also can be considered.

\section{Acknowledgements}

The authors would like to acknowledge the Institute of Research Management \& Innovation (IRMI), Universiti Teknologi MARA (UiTM) for funding the study with the project code $600-\mathrm{RMC} / \mathrm{GPK} 5 / 3$ (051/2020). Our profound gratitude also goes to the Malaysian Department of Environment (DOE) for air quality data.

\section{Conflicts of Interest}

The authors declare no conflicts of interest regarding the publication of this paper.

\section{References}

Abdullah, S., Ismail, M., \& Ahmed, A. N. (2018). Identification of Air Pollution Potential Sources through Principal Component Analysis (PCA). International Journal of Civil Engineering and Technology, 9, 1435-1442.

Adedeji, O. H., Oluwafunmilayo, O., \& Oluwaseun, T. A. O. (2016). Mapping of Traffic-Related Air Pollution Using GIS Techniques in Ijebu-Ode, Nigeria. The Indonesian Journal of Geography, 48, 73-83. https://doi.org/10.22146/ijg.12488

Afroz, R., Hassan, M. N., \& Ibrahim, N. A. (2003). Review of Air Pollution and Health Impacts in Malaysia. Environmental Research, 92, 71-77. https://doi.org/10.1016/S0013-9351(02)00059-2

Awang, M. B., Jaafar, A. B., Abdullah, A. M., Ismail, M. B., Hassan, M. N., Abdullah, R., \& Noor, H. (2000). Air Quality in Malaysia: Impacts, Management Issues, and Future Challenges. Respirology, 5, 183-196. https://doi.org/10.1046/j.1440-1843.2000.00248.x

Azam, M., Othman, J., \& Ara, R. (2016). Energy Consumption and Emission Projection for the Road Transport Sector in Malaysia: An Application of the LEAP Model. Environment, Development and Sustainability, 18, 1027-1047. https://doi.org/10.1007/s10668-015-9684-4

Azid, A., Juahir, H., Toriman, M. E., Endut, A., Kamarudin, M. K. A., Rahman, M. N. A. et al. (2015). Source Apportionment of Air Pollution: A Case Study in Malaysia. Jurnal Teknologi, 72, 83-88. https://doi.org/10.11113/jt.v72.2934

Azid, A., Juahir, H., Toriman, M. E., Kamarudin, M. K. A., Saudi, A. S. M., Hasnam, C. N. C. et al. (2014). Prediction of the Level of Air Pollution Using Principal Component Analysis and Artificial Neural Network Techniques: A Case Study in Malaysia. Water, Air, \& Soil Pollution, 225, Article No. 2063. https://doi.org/10.1007/s11270-014-2063-1

Azmi, S. Z., Latif, M. T., Ismail, A. S., Juneng, L., \& Jemain, A. A. (2010). Trend and Sta- 
tus of Air Quality at Three Different Monitoring Stations in the Klang Valley, Malaysia. Air Quality, Atmosphere \& Health, 3, 53-64. https://doi.org/10.1007/s11869-009-0051-1

Banan, N., Latif, M. T., Juneng, L., \& Ahamad, F. (2013). Characteristics of Surface Ozone Concentrations at Stations with Different Backgrounds in the Malaysian Peninsula. Aerosol Air Qual. Res. 13, 1090-1106. https://doi.org/10.4209/aaqr.2012.09.025

Department of Environment (DOE) (2011). Malaysia Environmental Quality Report 2011. Department of Environment.

Department of Environment (DOE) (2015). Malaysia Environmental Quality Report 2015. Department of Environment.

Department of Environment (DOE) (2017). Malaysia Environmental Quality Report 2017. Department of Environment.

Dominick, D., Juahir, H., Latif, M. T., Zain, S. M., \& Aris, A. Z. (2012). Spatial Assessment of Air Quality Patterns in Malaysia Using Multivariate Analysis. Atmospheric Environment, 60, 172-181. https://doi.org/10.1016/j.atmosenv.2012.06.021

Fang, C., Liu, H., Li, G., Sun, D., \& Miao, Z. (2015). Estimating the Impact of Urbanization on Air Quality in China Using Spatial Regression Models. Sustainability, 7, 15570-15592. https://doi.org/10.3390/su71115570

Ghaffarpasand, O., Beddows, D.C.S., Ropkins, K., \& Pope, F.D. (2020). Real-World Assessment of Vehicle Air Pollutant Emissions Subset by Vehicle Type, Fuel and Euro Class: New Findings from the Recent UK EDAR Field Campaigns, and Implications for Emissions Restricted Zones. Sci. Total Environ, 734, Article ID: 139416.

https://doi.org/10.1016/j.scitotenv.2020.139416

Gimond, M. (2021). Chapter 14. Spatial Interpolation. In Intro to GIS and Spatial Analysis. GitHub. https://mgimond.github.io/Spatial/spatial-interpolation.html

Hussein, J., \& Abdullah, A. (2019). Spatial Distribution of Criteria Pollutants in Klang Valley from 5 Monitoring Stations. International Journal of Multidisciplinary Approach, 5, 68-92.

Isiyaka, H. A., Toriman, E. M., \& Juahir, H. (2015). Application of Principal Component Analysis and Multiple Linear Regression for Air Pollution Modeling in Selected Monitoring Stations in Malaysia. Elixir International Journal, 83, 32957-32962.

Jamalani, M. A., Abdullah, A. M., Azid, A., Ramli, M. F., Baharudin, M. R., Bose, M. M. et al. (2016). Monthly Analysis of $\mathrm{PM}_{10}$ in Ambient air of Klang Valley, Malaysia. Malaysian Journal of Analytical Sciences, 20, 1159-1170. https://doi.org/10.17576/mjas-2016-2005-23

Jang, E., Do, W., Park, G., Kim, M., \& Yoo, E. (2017). Spatial and Temporal Variation of Urban Air Pollutants and Their Concentrations in Relation to Meteorological Conditions at Four Sites in Busan, South Korea. Atmospheric Pollution Research, 8, 89-100. https://doi.org/10.1016/j.apr.2016.07.009

Liu, Y., He, K.B., Li, S.S., Wang, Z. X., Christiani, D.C., \& Koutrakis, P. (2012). A Statistical Model to Evaluate the Effectiveness of $\mathrm{PM}_{2.5}$ Emissions Control during the Beijing 2008 Olympic Games. Environment International, 44, 100-105. https://doi.org/10.1016/j.envint.2012.02.003

Mackenzie, J., \& Turrentine, J. (2021, June 22). Air Pollution: Everything You Need to Know. https://www.nrdc.org/stories/air-pollution-everything-you-need-know

Makmom Abdullah, A., Armi Abu Samah, M., \& Yee Jun, T. (2012). An Overview of the Air Pollution Trend in Klang Valley, Malaysia. Open Environmental Sciences, 6, 13-19. https://doi.org/10.2174/1876325101206010013 
Mohd Zizi, N. A., Mohamed Noor, N., Izzah Mohamad Hashim, N., \& Yusuf, S. Y. (2018). Spatial and Temporal Characteristics of Air Pollutants Concentrations in Industrial Area in Malaysia. IOP Conference Series: Materials Science and Engineering, 374, Article ID: 012094. https://doi.org/10.1088/1757-899X/374/1/012094

Monteiro, A., Strunk, A., Carvalho, A., Tchepel, O., Miranda, A. I., Borrego, C., \& Elbern, H. (2012). Investigating a High Ozone Episode in a Rural Mountain Site. Environmental Pollution, 162, 176-189.

Nerriere, É., Zmirou-Navier, D., Blanchard, O., Momas, I., Ladner, J., Le Moullec, Y., Personnaz, M. B., Lameloise, P., Delmas, V., Target, A., \& Desqueyroux, H. (2005). Can We Use Fixed Ambient Air Monitors to Estimate Population Long-Term Exposure to Air Pollutants? The Case of Spatial Variability in the Genotox ER Study. Environmental Research, 97, 32-42. https://doi.org/10.1016/j.envres.2004.07.009

Papamanolis, N. (2015). The Main Characteristics of the Urban Climate and the Air Quality in Greek Cities. Urban Climate, 12, 49-64.

https://doi.org/10.1016/j.uclim.2014.11.003

Rahman, S., Syed Ismail, S., Raml, M., Latif, M. T., Zainal Abidin, E., \& Praveena, S. (2015). The Assessment of Ambient Air Pollution Trend in Klang Valley, Malaysia. World Environment, 5, 1-11.

Rajab, J. M., Tan, K. C., \& Jafri, M. Z. (2011). Investigation on the Carbon Monoxide Pollution over Peninsular Malaysia Caused by Indonesia Forest Fires from AIRS Daily Measurement. In F. Nejadkoorki (Ed.), Advanced Air Pollution (pp. 115-136). IntechOpen.

Sadanaga, Y., Sengen, M., Takenaka, N., \& Bandow, H. (2012). Analyses of the Ozone Weekend Effect in Tokyo, Japan: Regime of Oxidant $\left(\mathrm{O}_{3}+\mathrm{NO}_{2}\right)$ Production. Aerosol and Air Quality Research, 12, 161-168. https://doi.org/10.4209/aaqr.2011.07.0102

Sahrir, S., Abdullah, A. M., Ponrahono, Z., \& Sharaai, A. H. (2019). Environmetric Study on Air Quality Pattern for Assessment in Klang Valley, Malaysia. International Journal of Recent Technology and Engineering (IJRTE), 8, 17-24.

Sahrir, S., Bachok, S., \& Osman, M. M. (2014). Environmental and Health Impacts of Airport Infrastructure Upgrading: Kuala Lumpur International Airport 2. Procedia-Social and Behavioral Sciences, 153, 520-530. https://doi.org/10.1016/j.sbspro.2014.10.085

Saija, S., \& Romano, D. (2002). A Methodology for the Estimation of Road Transport Air Emissions in Urban Areas of Italy. Atmospheric Environment, 3636, 5377-5383. https://doi.org/10.1016/S1352-2310(02)00488-0

Sentian, J., Herman, F., Yih, C. Y., \& Wui, J. C. H. (2019). Long-Term Air Pollution Trend Analysis in Malaysia. International Journal of Environmental Impacts, 2, 309-324. https://doi.org/10.2495/EI-V2-N4-309-324

Shafie, S. H. M., \& Mahmud, M. (2020). Urban Air Pollutants from Motor Vehicle Emissions in Kuala Lumpur, Malaysia. Aerosol and Air Quality Research, 20, 2793-2804. https://doi.org/10.4209/aaqr.2020.02.0074

Shah, R. N., Abdullah, J., \& Ahmad, Z. (2010). The Physical Development of Port City. In Malaysian Universities Transportation Research Forum and Conference 2010 (pp. 269-278). Universiti Tenaga Nasional.

Tian, G. J., Qiao, Z., \& Xu, X. L. (2014). Characteristics of Particulate Matter $\left(\mathrm{PM}_{10}\right)$ and Its Relationship with Meteorological Factors during 2001-2012 in Beijing. Environmental Pollution, 192, 266-274. https://doi.org/10.1016/j.envpol.2014.04.036

Vallero, D. (2014). Fundamentals of Air Pollution. Academic Press. 


\section{https://doi.org/10.1016/C2012-0-01172-6}

Wang, S., Gao, S., Li, S., \& Feng, K. (2020). Strategizing the Relation between Urbanization and Air Pollution: Empirical Evidence from Global Countries. Journal of Cleaner Production, 243, Article ID: 118615. https://doi.org/10.1016/j.jclepro.2019.118615

Wei, X., Liu, Q., Lam, K. S. et al. (2012). Impact of Precursor Levels and Global Warming on Peak Ozone Concentration in the Pearl River Delta Region of China. Advances in Atmospheric Sciences, 29, 635-645. https://doi.org/10.1007/s00376-011-1167-4

World Health Organization (WHO) (2018, May 2). One-Third of Global Air Pollution Deaths in Asia Pacific.

https://www.who.int/westernpacific/news/detail/02-05-2018-one-third-of-global-air-po $\underline{\text { llution-deaths-in-asia-pacific }}$

Yan, S., Cao, H., Chen, Y., Wu, C., Hong, T., \& Fan, H. (2016). Spatial and Temporal Characteristics of Air Quality and Air Pollutants in 2013 in Beijing. Environmental Science and Pollution Research, 23, 13996-14007.

https://doi.org/10.1007/s11356-016-6518-3

Zakaria, U. A., Saudi, A. S. M., Abu, I. F., Azid, A., Balakrishnan, A., Amin, N. A., \& Rizman, Z. I. (2017). The Assessment of Ambient Air Pollution Pattern in Shah Alam, Selangor, Malaysia. Journal of Fundamental and Applied Sciences, 9, 772-788.

https://doi.org/10.4314/jfas.v9i4S.43

Zhou, C. S., Chen, J., \& Wang, S. J. (2018). Examining the Effects of Socioeconomic Development on Fine Particulate Matter $\left(\mathrm{PM}_{2.5}\right)$ in China's Cities Using Spatial Regression and the Geographical Detector Technique. Science of the Total Environment, 619-620, 436-445. https://doi.org/10.1016/j.scitotenv.2017.11.124 